\title{
Analisis Potensi dan Realisasi Penerimaan Pajak Hotel di Kabupaten Pemalang
}

\author{
Nita Benita ${ }^{1}$, David Adechandra², Ashedica Pesudo ${ }^{3}$
}

1,2,3 Fakultas Ekonomika Dan Bisnis, Universitas Kristen Satya Wacana

\section{A R T I C L E I N F O}

Received 19 February 2019

Received in revised form

16 March 2019

Accepted 15 April 2019

Available online 26 May 2019

\section{Kata Kunci:}

Pajak hotel

Keywords:

Hotel Tax

\begin{abstract}
A B S T R A K
Studi ini meneliti tentang potensi pajak hotel di Kabupaten Pemalang dari tahun 2014 sampai dengan tahun 2018. Tujuan dari penelitian ini ialah mencari potensi riil pajak hotel dan membandingkannya dengan realisasinya. Studi ini menggunakan metode kualitatif dan data yang digunakan ialah data sekunder yang didapatkan dari Bapenda Kabupaten Pemalang. Hasil dari penelitian ini menunjukkan bahwa potensi riil pajak hotel Kabupaten Pemalang pada tahun 2014 sebesar Rp 3.019.518.365 dan terus meningkat hingga pada tahun 2018 sebesar Rp 3.205.734.770. Begitu pula dengan efektivitas (perbandingan antara potensi pajak hotel dengan realisasi pajak hotel) yang selalu meningkat tiap tahunnya dan persentase paling besar ialah tahun 2018 sebesar 15,70 persen.
\end{abstract}

\section{A B S T R A C T}

This study research about the potential of hotel tax in Pemalang Regency from 2014 to 2018. The purpose of this study is to find the real potential of hotel taxes and compare them with their realization. This study uses qualitative methods and the data used is secondary data obtained from Bapenda, Pemalang Regency. The results of this study which showed the potential of Pemalang Regency hotel tax in 2014 amounted to $R p 3,019,518,365$ and continued to increase until 2018 amounting to $\mathrm{Rp} 3,205,734,770$. Likewise with effectiveness that always increases every year and the largest percentage in 2018 is 15.70 percent.

\footnotetext{
* Corresponding author.

E-mail addresses: theresianita70@gmail.com (Nita Benita)
} 


\section{Pendahuluan}

Dalam pelaksanaan pembangunan daerah, suatu daerah tentu membutuhkan pemasukan untuk pembiayaan-pembiayaan yang diperlukan karena tiap-tiap daerah dituntut untuk mandiri. Untuk itu Pemerintah daerah diberi otonomi dengan maksud supaya suatu daerah bisa mandiri mengatur urusan rumah tangganya dan tidak bergantung pada Pemerintah pusat. Dan berhasilnya otonomi daerah diukur dengan keuangan suatu daerah yang merupakan faktor pengukur keberhasilannya (Alista 2014). Dengan Pendapatan Asli Daerah (PAD), tiap daerah dapat mengurus sendiri urusan rumah tangga daerah. Berdasarkan Undang-Undang Nomor 33 Tahun 2004 tentang Perimbangan Keuangan Antara Pusat dan Daerah dijelaskan bahwa PAD adalah pendapatan yang diperoleh daerah yang dipungut berdasarkan peraturan daerah sesuai dengan peraturan perundang-undangan.

PAD berisikan pendapatan pajak daerah, retribusi daerah, pendapatan hasil pengelolaan kekayaan daerah yang dipisahkan serta lain-lain pendapatan asli daerah yang sah. Menurut Kobandaha dan Wokas (2016) menyatakan bahwa PAD merupakan sumber penerimaan daerah yang berperan penting guna melaksanakan pembangunan daerah. Maka dari itu, komponen-komponen yang mendukung untuk meningkatkan PAD harus digali dengan maksimal supaya mendapatkan penerimaan daerah yang optimal. Untuk meminimalisir ketergantungan pemerintah daerah terhadap pemerintah pusat dan dalam pelakasanaan kegiatan pembangunan di daerah akan sangat terbantu oleh besarnya penerimaan daerah dari sektor PAD (Alista 2014). Salah satu komponen dari PAD yang akan dibahas dalam penelitian ini ialah pajak hotel yang merupakan bagian dari pajak daerah

Pendapatan pajak daerah masih perlu ditingkatkan untuk memaksimalkan PAD (Sugiarto, Danurdara dan Rofi 2015). Berdasarkan Peraturan Daerah Kabupaten Pemalang Nomor 1 tahun 2012 tentang Pajak Daerah, yang dimaksud dengan Pajak Daerah adalah salah satu sumber pendapatan daerah yang penting guna membiayai pelaksanaan pemerintahan daerah dalam melaksanakan pelayanan kepada masyarakat serta mewujudkan kemandirian daerah. Untuk menggerakan partisipasi rakyat kepada negara, pajak merupakan alat yang paling efekktif dari kebijakan fiskal (Rahayu dan Purwanti 2012). Menurut Andaria, Utami dan Effendy (2015) pengelolaan pajak sebagai sumber penerimaan pokok bagi PAD yang efisien dapat memandirikan otonomi suatu daerah. Salah satu pajak daerah yang dipungut oleh pemerintah daerah ialah pajak hotel.

Berdasarkan UU No. 28 Tahun 2009 Pasal 1 angka 20 dan 21, pajak hotel adalah pajak daerah atas pelayanan yang disediakan oleh hotel. Hotel ialah fasilitas yang menyediakan jasa penginapan termasuk jasa lainnya yang memungut bayaran, yang mencakup losmen, motel, gubuk pariwisata, wisma pariwisata, pesanggrahan rumah penginapan dan sejenisnya, serta rumah kos dengan jumlah kamar lebih dari sepuluh (Putri, Kumadji dan Darono 2014). Pajak hotel merupakan pajak yang dikenakan atas pelayanan yang disediakan oleh hotel serta mencakup seluruh persewaan di hotel. Pajak hotel di Kabupaten Pemalang memiliki potensi yang sangat besar. Kabupaten Pemalang merupakan tempat yang kaya akan potensi pariwisata. Letaknya wilayahnya yang berupa gunung, hutan dan pantai, dapat memicu daya tarik dan kunjungan para wisatawan dari berbagai daerah. Industri perhotelan salah satu yang memiliki kontribusi besar dalam kaitannya dengan industri pariwisata (Cahyadi 2015). Industri perhotelan berkontribsi besar dalam sumbangsihnya pada penerimaan daerah yang berupa pajak hotel (Sugiarto, Danurdara dan Rofi 2015).

Berdasarkan Peraturan Daerah Kabupaten Pemalang No. 1 Tahun 2012, tentang pajak hotel, tarif pajak hotel ditetapkan sebesar sepuluh persen. Besaran pokok pajak hotel yang terutang dihitung dengan cara mengalikan tarif pajak yaitu sepuluh persen dengan dasar pengenaan pajak yaitu jumlah pembayaran atau yang seharusnya dibayar kepada hotel. Pajak hotel di Kabupaten Pemalang memiliki potensi yang cukup tinggi meskipun kontribusinya terhadap PAD kecil karena berada pada angka di bawah sampai dengan satu persen. Terlihat pada tabel 3 lampiran 1 yang menunjukkan realisasi penerimaan pajak hotel yang selalu melampaui target dan pada tabel 2 lampiran 1 yang memperlihatkan bahwa kontribusi pajak hotel terhadap pajak daerah yang hanya berkisar di nol sampai satu persen. Artinya bahwa realisasi penerimaan pajak hotel belum menunjukkan potensi yang seharusnya. Penetapan target yang hanya berdasar pada tahun sebelumnya salah satu penyebab selisih target dan realisasi (Sugiarto, Danurdara dan Rofi 2015).

Penelitian ini merupakan replikasi dari Jurnal Sugiarto, Danurdara dan Rofi (2015) yang berjudul “Analisis Potensi Penerimaan Pajak Hotel di Kabupaten Pemalang Jawa Tengah". Maka perhitungan potensi pajak hotel dan efektivitas pengelolaan pajak hotel diukur menggunakan rumus yang digunakan Sugiarto, Danurdara dan Rofi. Perhitungan potensi pajak hotel diperoleh berdasarkan data yang ada berupa, jumlah hotel, tarif kamar rata-rata, jumlah hari dan tingkat hunian Sugiarto, Danurdara dan Rofi (2015). Perhitungan efektivitas pengelolaan pajak hotel dapat dilakukan setelah mendapat perhitungan 
potensi dengan cara membandingkan potensi tersebut dengan realisasi pajak hotel (Sugiarto, Danurdara dan Rofi 2015).

Dengan demikian, persoalan dalam penelitian ini sebagai berikut: Bagaimana perbandingan antara realisasi penerimaan pajak hotel dengan potensi pajak hotel Kabupaten Pemalang? Maka penelitian ini diharapkan dapat memberi manfaat bagi Badan Pengelolaan Pendapatan Daerah (Bapenda) Kabupaten Pemalang guna mengetahui potensi pajak hotel yang sesungguhnya dan dapat menetapkan target pajak hotel sesuai dengan potensi riil sehingga efektivitas penerimaan pajak hotel Kabupaten Pemalang bisa maksimal.

\section{Metode}

Jenis penelitian ini adalah studi pada Badan Pengelolaan Pendapatan Daerah (Bapenda) Kabupaten Pemalang. Dalam penelitian ini menggunakan metode kualitatif dan data yang digunakan ialah data sekunder. Data sekunder diperoleh dari Bapenda Kabupaten Pemalang. Data-data yang diperoleh dari Bapenda merupakan data time series berupa target dan realisasi penerimaan PAD, pajak hotel dari tahun 2014-2018, data jumlah hotel, jumlah kamar dalam tiap hotel, dan tarif kamar per hari pada tiap hotel.

Satuan amatan dalam penelitian ini adalah hotel yang beroperasi di Kabupaten Pemalang termasuk hotel bintang dan non bintang, wisma, pondok wisata dan kos-kosan yang lebih dari sepuluh kamar. Sedangkan satuan analisis dalam penelitian ini ialah.hotel, wisma, pondok wisata dan kos-kosan yang lebih dari sepuluh kamar yang datanya dimiliki oleh Bapenda Kabupaten Pemalang.

Tahapan penelitian yang akan dilakukan oleh peneliti yaitu: pertama, mengumpulkan data hotel, wisma, pondok wisata dan kos-kosan yang jumlah kamar lebih dari sepuluh, target dan realisasi penerimaan pajak daerah, termasuk pajak hotel. Data-data tersebut diperoleh dari Bapenda. Setelah mendapatkan data hotel, wisma, pondok wisata dan kos-kosan yang jumlah kamar lebih dari sepuluh maka selanjutnya ialah mencari data jumlah kamar, tarif kamar per hari guna perhitungan potensi pajak hotel.

Kedua, setelah diperoleh hasil potensi pajak hotel maka yang selanjutnya adalah mencari efektivitas penerimaan pajak hotel. Dengan membandingkan potensi pajak hotel dengan realisasi penerimaan pajak hotel maka dapat diketahui efektivitas penerimaan pajak hotel.

Analisis perhitungan potensi mutlak diperukan dalam analisis menetapkan target rasional. Untuk menghitung potensi, dan efektivitas penerimaan pajak hotel, peneliti menggunakan rumus yang digunakan oleh Sugiarto, Danurdara dan Rofi (2015) di dalam penelitiannya.

$$
\text { Tarif kamar rata }- \text { rata }=\frac{(X 1 \times Y 1)+(X 2 \times Y 2)+(X 3 \times Y 3)}{Z}
$$

X1 : Jumlah kelas kamar suite

$\mathrm{X} 2$ : Jumlah kelas kamar deluxe

X3 : Jumlah kamar standar

$\mathrm{Z}$ : Total jumlah kamar
Y1 : Tarif kamar suite

Y2 : Tarif kamar deluxe

Y3 : Tarif kamar standar

Potensi pajak hotel dapat diketahui dengan rumus yang digunakan oleh Sugiarto, Danurdara dan Rofi (2015) dengan modifikasi perhitungan Bapenda:

\section{Potensi Pajak Hotel $=A x B \times 365$ hari $x 10 \% \times C$}

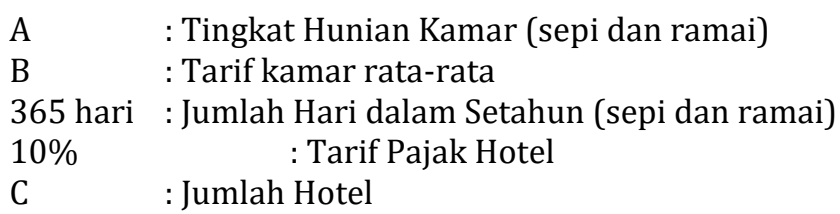

Digunakan beberapa asumsi untuk memberi batasan dan definisi terkait variabel-variabel yang digunakan, antara lain:

Jumlah hari dalam setahun : 365 hari

Tarif pajak hotel $\quad: 10 \%$

Selanjutnya, setelah diketahui potensi pajak hotel, dapat juga mengukur efektivitas penerimaan pajak menggunakan cara sebagai berikut: 


\section{Efektivitas $=\frac{\text { Realisasi Penerimaan Pajak Hotel }}{\text { Potensi Pajak Hotel }} \times 100 \%$}

Tahapan ketiga dalam penelitian ini, setelah menganalisis potensi pajak hotel dan efektivitas penerimaan pajak hotel ialah menarik kesimpulan atas analisis tersebut.

\section{Hasil dan pembahasan}

Dengan menghitung potensi yang sesungguhnya maka penerimaan pajak daerah dalam sektor perhotelan dapat digali secara efektif dan maksimal. Dengan perhitungan potensi pajak hotel ini, penetapan target pajak hotel suatu kabupaten menjadi lebih relevan dibandingkan dengan hanya menerapkan target progresif dari tahun sebelumnya. Untuk perhitungan potensi pajak hotel pada setiap tahunnya maka harus diketahui jumlah hotel di tiap-tiap tahun. Tarif rata-rata kamar juga perlu diketahui guna perhitungan potensi pajak hotel tersebut. Tarif rata-rata diperoleh dengan mengetahui jenis kamar, total kamar dan tarifnya.

Dari hasil perhitungan maka diperoleh potensi pajak hotel Kabupaten Pemalang dalam kurun waktu 2012-2016 ialah sebagai berikut:

Tabel 1. Potensi Pajak Hotel Kabupaten Pemalang Tahun 2014-2018

\begin{tabular}{cc}
\hline Tahun & Potensi Pajak Hotel \\
\hline 2014 & Rp 3.019.518.365 \\
2015 & Rp 3.019.518.365 \\
2016 & Rp 3.107.127.916 \\
2017 & Rp 3.205.734.770 \\
2018 & Rp 3.205.734.770 \\
\hline
\end{tabular}

Potensi pajak hotel Kabupaten Pemalang secara umum meningkat. Meskipun, pada tahun 2015 dan 2018 menunjukkan hasil yang statis. Dengan hasil perhitungan potensi pajak hotel tersebut dan juga datadata dari Bapenda yaitu berupa data target dan realasasi penerimaan pajak hotel, dapat dihitung suatu perbandingan antara potensi pajak hotel dengan realisasi penerimaan pajak hotel terhadap target yang sudah ditetapkan oleh Bapenda. Sejalan dengan penelitian yang dilakukan Pujiasih dan Wardani (2014) di Sleman yang menyatakan bahwa potensi pajak hotel belum tergali dengan maksimal sehingga realisasi penerimaan pajak hotel yang dipungut secara maksimal sesuai dengan potensi riil.

Tabel 2. Perbandingan Target Pajak Hotel, Realisasi Penerimaan Pajak Hotel Terhadap Potensi Pajak Hotel, Realisasi Penerimaan Pajak Hotel Terhadap Target Pajak Hotel Kabupaten Pemalang Tahun 2014-2018

\begin{tabular}{cccccccc}
\hline Tahun & $\begin{array}{c}\text { Potensi } \\
\text { dengan } \\
\text { pendekatan } \\
\text { rumus } \\
\text { (ribuan) }\end{array}$ & $\begin{array}{c}\text { Potensi } \\
\text { Sesuai } \\
\text { Hitungan } \\
\text { Bapenda } \\
\text { (ribuan) }\end{array}$ & $\begin{array}{c}\text { Realisasi } \\
\text { (ribuan) }\end{array}$ & $\begin{array}{c}\text { Target } \\
\text { (ribuan) }\end{array}$ & $\begin{array}{c}\text { Proporsi } \\
\text { Target } \\
\text { terhadap } \\
\text { Potensi } \\
(\%)\end{array}$ & $\begin{array}{c}\text { Proporsi } \\
\text { Realisasi } \\
\text { terhadap } \\
\text { Target } \\
(\%)\end{array}$ & $\begin{array}{c}\text { Proporsi } \\
\text { Realisasi } \\
\text { terhadap } \\
\text { Potensi } \\
(\%)\end{array}$ \\
\hline 2014 & $3.019 .518,4$ & $987.247,8$ & $231.207,9$ & 200.000 & 6,62 & 115,60 & 7,66 \\
2015 & $3.019 .518,4$ & $987.247,8$ & $280.441,8$ & 230.000 & 7,62 & 121,93 & 9,29 \\
2016 & $3.107 .127,9$ & $1.029 .907,8$ & $308.953,1$ & 260.000 & 8,37 & 118,83 & 9,94 \\
2017 & $3.205 .734,8$ & $1.101 .052,8$ & $374.277,4$ & 310.000 & 9,67 & 120,74 & 11,68 \\
2018 & $3.205 .734,8$ & $1.101 .052,8$ & $503.123,2$ & 350.000 & 10,92 & 143,75 & 15,70 \\
\hline & & & & & & Sumber: Data Olahan (2019)
\end{tabular}

Pada Tabel 2 di atas, menunjukkan perbedaan antara potensi pajak hotel Kabupaten Pemalang yang dihitung antara penulis dengan Bapenda. Hal tersebut dikarenakan penulis tidak mendapatkan data asumsi-asumsi yang digunakan oleh Bapenda sebagai pengurang pendapatan hotel. Proporsi target pajak hotel terhadap potensi pajak hotel dari tahun 2014 sampai dengan tahun 2018 selalu meningkat. Tahun 2018 ialah tahun dengan persentase tertinggi yaitu sebesar 10,92 persen. Dari hasil perhitungan tersebut menunjukkan bahwa target yang ditetapkan oleh Bapenda masih belum maksimal melihat selisihnya 
dengan potensi pajak hotel yang besar. Proporsi realisasi terhadap target menunjukkan hasil persentase yang fluktuatif. Setiap tahun realisasi penerimaan selalu meningkat dan melampaui dari target yang ditetapkan. Sedangkan proporsi realisasi terhadap potensi setiap tahunnya menunjukkan hasil yang selalu meningkat. Meskipun realisasi penerimaan pajak hotel selalu melampaui target yang ditetapkan, akan tetapi realisasi penerimaan masih memiliki selisih yang besar dengan potensi riil.

Dan untuk mengetahui besarnya efektivitas penerimaan pajak hotel di Kabupaten Pemalang, langkah pertama ialah membandingkan antara realisasi dengan potensi pajak hotel dalam kurun waktu 2014-2018.

Tabel 3. Efektivitas Pajak Hotel Kabupaten Pemalang Tahun 2014-2018

\begin{tabular}{ccccc}
\hline Tahun Anggaran & Realisasi Pajak Hotel & Potensi Pajak Hotel & Selisih & Efektivitas \\
\hline 2014 & Rp 231.207.900 & Rp 3.019.518.365 & Rp 2.788.310.465 & $7,66 \%$ \\
2015 & Rp 280.441.800 & Rp 3.019.518.365 & Rp 2.739.076.565 & $9,29 \%$ \\
2016 & Rp 308.953.100 & Rp 3.107.127.916 & Rp 2.798.174.816 & $9,94 \%$ \\
2017 & Rp 374.277.400 & Rp 3.205.734.770 & Rp 2.831.457.370 & $11,68 \%$ \\
2018 & Rp 503.123.200 & Rp 3.205.734.770 & Rp 2.702.611.570 & $15,70 \%$ \\
\hline
\end{tabular}

Hasil persentase yang semakin besar bisa diartikan bahwa pemungutan pajak hotel semakin efektif, begitu sebaliknya Ardiles dan Mulyani (2014). Efektifitas pada tahun 2014-2015 dapat dikatakan baik karena setiap tahunnya mengalami peningkatan. Efektivitas paling besar ialah pada tahun 2018.

Berdasarkan kajian yang dilakukan oleh Bapenda, pemasangan tapping box yang baru dilakukan pada tahun 2018 dan baru terpasang pada dua hotel yaitu hotel R-gina dan hotel The Winner Premier membuat penerimaan pajak hotel meningkat. Tapping box merupakan alat yang digunakan untuk merekam setiap transaksi, maka Bapenda akan sangat dimudahkan dalam mengontrol transaksi-transaksi yang terjadi pada hotel tersebut. Seperti terlihat pada tabel 7, pada tahun 2018 efektivitas penerimaan pajak hotel sebesar 15,70 persen.

Meningkatan penerimaan pajak hotel bukan pekerjaan yang mudah. Seperti dalam kajian Bapenda tentang pajak hotel, Pemerintah Kabupaten Pemalang perlu membuat beberapa kebijakan strategis guna mendukung usahanya dalam meningkatkan penerimaan pajak hotel. Terbagi menjadi dua bagian, yaitu kebijakan optimalisasi atas potensi riil yang ada, dan kebijakan dalam rangka meningkatkan penerimaan pajak hotel di tahun-tahun berikutnya.

Pada strategi optimalisasi atas potensi riil terdapat beberapa dua poin, yang pertama yaitu meningkatkan willingness to pay yang dapat dikatakan bahwa adanya kesadaran dan kesediaan para wajib pajak hotel untuk membayar pajak sesuai dengan ketentuan yang ada merupakan faktor yang fundamental. Adanya insentif, yang lansung dan tidak langsung yang diberikan oleh Pemerintah Kabupaten Pemalang akan mendorong kesadaran wajib pajak untuk membayar pajak hotel. Poin kedua ialah kebijakan strategis dan yang dilakukan oleh Pemerintah Kabupaten Pemalang adalah moderinsasi sistem perpajakan daerah khususnya pajak hotel supaya lebih efektif, menyelenggarakan event-event yang mampu mengundang wisatawan dari luar Kabupaten Pemalang, memenuhi sarana dan prasarana yang mendukung industri perhotelan.

Selanjutnya, strategi peningkatan penerimaan pajak hotel. Dalam strategi ini, untuk meningkatkan penerimaan pajak hotel perlu kebijakan strategis jangka panjang, seperti menciptakan kondisi makro ekonomi yang baik, menyusun kebijakan pengembangan pariwisata yang dapat menarik pengunjung dari luar Kabupaten Pemalang, Menyusun kebijakan yang pro investasi dan dunia bisnis agar menarik banyak orang datang ke Kabupaten Pemalang, serta melakukan perubahan peraturan terkait pajak hotel agar mampu mengikuti perkembangan dunia usaha dan perkembangan dunia usaha dan perkembangan teknologi informasi.

Berdasarkan penelitian-penelitian sebelumnya terdapat selisih yang sangat besar jika membandingkan antara target pajak hotel dengan potensi riil penerimaan pajak. Penetapan target masih terlalu kecil pada Kota Palangka Raya. Namun, secara keseluruhan pemungutan pajak hotel sudah efektif dengan persentase tingkat efektivitas mencapai 89 persen (Toding 2016). Begitu pula yang terjadi pada Kota Mojokerto, terdapat selisih yang besar antara target pajak hotel dengan potensi pajak hotel. Untuk tingkat efektivitas pada Kota Mojokerto rata-rata memiliki efektivitas sebesar 27,12 persen (Khotimah 2014). Penelitian yang dilakukan oleh Jaya dan Widuri (2013) di Surabaya juga menunjukkan bahwa potensi pajak hotel di Surabaya memiliki selisih yang signifikan dengan realisasinya. 


\section{Simpulan dan saran}

Potensi pajak hotel Kabupaten Pemalang memiliki selisih yang sangat besar dengan realisasi penerimaan pajak hotel. Meskipun, potensi pajak hotel Kabupaten Pemalang setiap tahunnya mengalami peningkatan dan yang terbesar ialah tahun 2018. Untuk tingkat efektivitas penerimaan pajak hotel setiap tahunnya meningkat tapi persentasenya masih rendah. Tingkat efektivitas tertiggi terjadi pada tahun 2018.

Data tingkat hunian yang menjadi dasar dalam perhitungan potensi pajak hotel Kabupaten Pemalang di dapatkan dari wawancara pemilik/karyawan hotel, sehingga kejujuran dari responden sangat berpengaruh terhadap hasil perhitungan potensi pajak hotel. Penulis tidak mendapatkan data asumsi-asumsi pengurang pendapatan hotel yang digunakan oleh Bapenda selain diskon.

Pada tahun 2018, Bapenda telah melakukan kajian tentang potensi pajak hotel, hendaknya target pajak hotel ditetapkan berdasarkan hasil perhitungan dari hasil kajian tersebut dan tidak hanya mengacu pada tahun-tahun sebelumnya. Pemasangan taping box disarankan untuk dipasang pada setiap hotel yang ada di Kabupaten Pemalang guna meminimalisir kecurangan yang dilakukan wajib pajak. Dengan tapping box, Bapenda juga dapat mengetahui tingkat hunian yang semestinya. Untuk meningkatkan kesadaran wajib pajak, Pemerintah Daerah juga perlu effort untuk mengembangkan fasilitas-fasilitas yang dapat menunjang keberlangsungan industri perhotelan, seperti memodernisasi sistem perpajakan supaya wajib pajak dimudahkan dalam membayar dan melaporkan pajaknya, juga pemenuhan sarana dan prasarana yang mendukung industri perhotelan. Pemerintah Daerah dituntut juga untuk dapat memberikan insetif berupa reward kepada wajib pajak hotel yang taat, namun juga memberikan punishment untuk wajib pajak yang kedapatan melanggar peraturan perpajakan.

Untuk penelitian selanjutnya, diharapkan sudah bisa mengetahui tingkat hunian yang sesungguhnya dan Bapenda dapat memberikan data mengenai asumsi-asumsi yang digunakan dalam perhitungan pendapatan hotel..

\section{Daftar Rujukan}

Alista, Hervia Nanda. "Analisis Faktor-Faktor yang Mempengaruhi Realisasi Jumlah Penerimaan Pajak Hotel." Jurnal Ilmiah Mahasiswa FEB Vol 3, No 1 (2014): 1-18.

Andaria, Shofiatul, Hamida Nayati Utami, and Idris Effendy. "Analisis Efektivitas dan Kontribusi Pajak Hotel Bagi Penerimaan Pendapatan Asli Daerah di Kabupaten Malang." Jurnal Perpajakan (JEJAK) Vol. 7 No. 1 (2015): 2-7.

Ardiles, and Erly Mulyani. "Analisis Potensi dan Kontribusi Pajak Hotel Terhadap Pendapatan Asli Daerah Pemerintah Kota Padang." Jurnal WRA Vol 2, No 1 (April 2014): 1-16.

Badan Pendapatan Daerah (Bapenda). "Analisis Potensi Pajak Hotel Kabupaten Pemalang." 2018.

Cahyadi, Robi. "Pengaruh Pajak Industri Pariwisata dan Retribusi Obyek Wisata Terhadap Pendapatan Asli Daerah (PAD) di 12 Kabupaten/Kota Provinsi Riau Tahun 2009-2013." Jom FEKON No 2. Vol.2 (Oktober 2015): 1-15.

Jaya, Lisa Hendra, and Retnaningtyas Widuri. "Analisis Potensi Pajak Hotel Terhadap Realisasi Penerimaan Pajak Hotel Berbintang di Surabaya." TAX \& ACCOUNTING REVIEW VOL.1, NO.1 (2013): $1-5$.

Khotimah, Qusnul. "Analisis Potensi dan Efektivitas Penerimaan Pajak Hotel Dalam Meningkatkan Pendapatan Asli Daerah." Jurnal Ilmiah Mahasiswa FEB Vol 2, No 2 (2014): 1-13.

Kobandaha, Rezlyanti, and Heince R. N. Wokas. "Analisis Efektivitas Kontribusi Dan Potensi Pajak Reklame Dan Pajak Hotel Terhadap Pendapatan Asli Daerah Kota Kotamobagu." Jurnal EMBA Vol.4 No.1 (Maret 2016): 1461-1472.

Pemerintah Republik Indonesia. "Peraturan Daerah Nomor 1." 2012.

Pemerintah Republik Indonesia. "Undang-Undang No.28." 2009. 
Pemerintah Republik Indonesia. "Undang-Undang Nomor 33." 2004.

Pujiasih, Rofian, and Dewi Kusuma Wardani. "Analisis Potensi, Efektifitas dan Kontribusi Pajak Hotel Terhadap Pendapatan Asli Daerah Kabupaten Sleman." Jurnal Akuntansi Vol. 2 No.2 (Desember 2014): 1-12.

Putri, Roro Bella Ayu Wandani Prasetio, Srikandi Kumadji, and Agung Darono. "Analisis Penerimaan Pajak Hotel, Pajak Restoran, Pajak Hiburan Sebagai Sumber Pendapatan Asli Daerah." Jurnal Perpajakan Vol. 3 No. 1 (Desember 2014): 1-8.

Rahayu, Betty, and Evi Yulia Purwanti. "Analisis Potensi Pajak Hotel Terhadap Realisasi Penerimaan Pajak Hotel di Kabupaten Gunungkidul." MEDIA EKONOMI DAN MANAJEMEN Vol 26. No 2 (Juli 2012): 113.

Rawung, Megha Cicilia, Herman Karamoy, and Inggriani Elim. "Analisis Potensi Penerimaan Pajak Hotel di Kota Tomohon." Jurnal Accountability Vol 4, No 1 (2015): 1-11.

Sugiarto, Yayan, Ananta Budhi Danurdara, and Nur Rofi. "Analisis Potensi Penerimaan Pajak Hotel di Kabupaten Pemalang Jawa Tengah." Jurnal BARISTA Volume 2, Nomor 1 (Juli 2015): 1-15.

Toding, Ronald Bua. "Analisis Potensi Dan Efektivitas Pemungutan Pajak Hotel Dalam Meningkatkan Pendapatan Asli Daerah Kota Palangka Raya." Jurnal EMBA Vol.4 No.1 (Maret 2016): 1-9. 